\title{
FOLKLORE INTRODUCES: INGRID SLAVEC GRADIŠNIK
}

\section{MY "ROOTS"}

I was born in Koper, at the seaside, in an area that is officially bilingual, Slovenian-Italian, and situated close to what is now the former Yugoslav-Italian border. In a way I feel this has marked my view, which I could say to have been curious and opening towards the horizon. As a little girl, I was looking from the home balcony towards the Debeli rtič cape, where there remains the open European border with Italy, and beyond toward Grado/Monfalcone - which is as far as you could see on a sunny day. And I kept saying that it was Venice. Far beyond the hills on the north side, also when the weather was nice, you could see the highest Slovenian mountain, Triglav, and far to the right, in the east, there was Nanos, a milestone of a kind between the Primorska region and Central Slovenia. Coming from the southeast and south, the miraculous Istrian landscape was radiating, that is, its Slovenian part that had always been the natural hinterland of three Slovenian seaside towns - Koper, Izola and Piran, as well as the peninsular Croatian part eating into the waves of the northern Adriatic Sea.

A special place of my childhood - apart from Koper - was Trst/Trieste: even in socialism it was a habit (and tradition) for numerous women from the Istrian hinterland to work for wealthy Trieste families

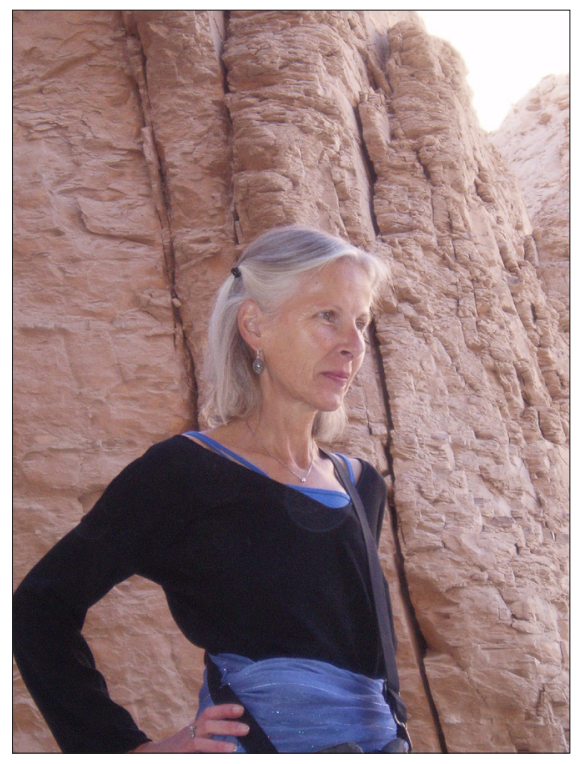

Ingrid Slavec Gradišnik. 
and earn an additional income, both to provide for their own families and to be able to afford all the goods that were not available in the socialist Yugoslavia. Border residents had special passports, the so-called passes (It. lasciapassare), which enabled us to visit Italy four times a month, and later in the 1970s even more often. We would buy washing powder, footwear, textiles in Muggia, a small town ahead of Trieste, and in Trieste itself. Before Euros, in Italy you would pay in lire, which women also earned by taking a kilo of meat, a packet of butter, and eggs to Trieste and exchanging these for household items with drugstore owners. It would be difficult ever to forget the journeys to Trieste by a boat that departed from Koper two or three times daily, and the excellent ice-cream in Trieste, which my mother would buy for me.

During secondary school, I started to see Trieste differently: it was where I would go to buy music (the famed LPs), books, see art exhibitions, visit cinemas and theatres. This, apart from Italian television, was a window on the so-called "Western" world, as well as a reflection of the glitter of Austro-Hungarian monarchy's westernmost part, and to me it still remains an exciting combination of Central and Mediterranean Europe. And also a city where Slovenians have found it hard to reside form the Fascist times onwards!

When in the mid-1970s I came to Ljubljana to study, I noticed that the horizon of people living near the Italian border was a bit "different". It was as if we had been carrying in us a different spirit that was difficult to grasp. I found the decision about what to study easy and difficult at the same time. With my interests going in the cultural and humanistic direction, as well as languages (I had been learning Italian and English since primary school, also French in secondary school), I knew exactly what not to study. At the Faculty of Arts, I could study anything. I enrolled for the double-subject study of Slovenian language and literature (the major or A subject) and history of art (the minor or B subject).

\section{EDUCATION}

My secondary school teachers were mostly excellent and I was particularly inspired by a young teacher of Slovenian language and literature, who once invited her colleague with a degree in ethnology to our school literary group. This was probably the first time I had heard about ethnology. The talk with him remained somewhere at the back of my mind until the long holidays after the matura exam and before entering the university. Then, travelling around Europe, close to Copenhagen, I found myself in the company of two boys and a girl who studied ethnology. I realised how ethnology was opening up a view 
towards everything I was really interested in: the diversity of cultures, histories, places, people and their fates. And so, when enrolling officially at the university, I swiftly replaced art history with ethnology, and after the first year registered it as the second major (A).

\section{UNIVERSITY}

Many are disappointed with their studies. I wasn't. I kept in mind what the secondary school class teacher told us as a farewell, saying that surely we believed it was the end of annoying classes, but even in what we had chosen to study, we would still find at least half of the classes and obligations to be redundant and off-putting. I have always loved literature, whereas studying the secrets of my mother tongue has given me many valuable things - first, it made me aware of my own literacy, but mostly it made me realize how the world and relations between people in their most part are actually interlaced in the language. Today, for example, this knowledge helps me also with my editorial work. On the other hand, at the Department of Ethnology, there was Professor Vilko Novak, an eminent expert on philology and ethnology, who kept persuading me about the importance of philological education. When I began my studies, he was the only full professor at the department, and lectured on the ethnology of Slovenians, ethnology of Southern Slavs and European ethnology. Naturally, I only began to appreciate him after I finished my studies, and later on in my career path. Except for two or three assistants, the second lecturer at the department was the associate professor Slavko Kremenšek, who had been introducing "revolutionary" views into Slovenian ethnology since the $1960 \mathrm{~s}$. He turned the future development of our discipline away from its traditional ethnographic frameworks, which he achieved particularly by focusing ethnological research elsewhere than solely on the past, on rural areas and the remnants of the "old" culture. To student generations of the 1970s and 1980s, he opened up a perspective on everyday culture, contemporary cultural manifestations and cities, and related past and contemporary cultural phenomena to various generational, social, professional and local groups. It could be said that he provided research into everyday life with social-anthropological foundations, which see culture not as a single and unique entity but as a strongly historically and socially informed phenomenon. He thus balanced the relationship between the discipline's practice and theory. He became my mentor in the noblest sense of the word. 


\section{MY INTERESTS}

I was particularly drawn by theoretical aspects, which was due to several reasons: intimately, I had always been interested in the adventures of the human spirit, and - which is already related to ethnology - in theory I saw the key non-explicated or explicated stock of knowledge, which, apart from the skill of narration, is what to a great extent creates inspiring or lame, "better" or "worse" ethnological/anthropological texts, which are more or less convincing in the sense of thematising both universal and specific phenomena of human existence. The first founding-fathers that I read with such a sensibility, of course, were Malinowski and Lévi-Strauss.

\section{MY BA DEGREE}

My diploma thesis on the Slovenians in Mannheim, Germany, served two purposes: it was prepared in the seminar dedicated to the research of Slovenian emigrants and it integrated my Slovenian and ethnological studies; it was also admitted as a diploma thesis at both departments. My main topic of interest was linguistic communication both in German and in Slovenian, as was then practiced in Slovenian families living abroad due to temporary working migration. In principle it explored bilingual asymmetry, which is typical of migrant communities, but not as a unified concept because communicative practices in the mother tongue and in a foreign language depend largely on the social position, education, social networks, contacts with the country of origin, future plans (to remain abroad or return home), etc., and eventually on the attitude towards the mother tongue and homeland in general.

\section{EMPLOYMENT}

During my studies, I wasn't worrying about what to do for a living. Actually, there weren't many jobs in ethnology: at the time ethnologists would mostly work in museums, in institutes for heritage protection, whereas the majority of them would find jobs based on their education in other specialties. Towards the end of my studies I somehow knew I didn't want to be a secondary school Slovenian teacher. I really wanted and hoped to do something related to ethnology. Already while studying, I helped in the department library on a regular basis, thus learning about library and secretarial duties. Since I was a good student, Prof Kremenšek would have offered me a position as an assistant if it 
had been possible, but it wasn't. As the then librarian was just switching jobs, I thus came to the library after graduating, to the world I love so much - being surrounded by books. I stayed there for four years until a position for an assistant in general ethnology was opened.

\section{PhD RESEARCH}

In the meantime I began my postgraduate studies, the topic of my postgraduate thesis having been the development, or rather, a thorough overview of the tendencies in post-World War II ethnology in Slovenia. The topic then grew so much that the professor advised me to elaborate it as a doctoral thesis. As in the following years I undertook a series of lectures and seminars, which together with other work with students occupied all of my time, and became a mother, I was quite late in obtaining my $\mathrm{PhD}$, only when turning 42 . By then I had thoroughly studied the history of ethnology in Slovenia and abroad, which convinced me of the cumulative nature of knowledge production in humanities, and of the need to balance historicist and presentist approaches in dealing with the history of the discipline. The most valuable of the findings, as I thought and as was later affirmed by research into the formation and work of individual researchers, was that the so-called objective aspects or determinants that institute, co-produce and govern the discipline's trends, coexist with a number of ostensible contingencies of a more subjective nature (individuals' affinities and characters, their views of the world, individual trajectories, interpersonal and institutional networks, reception of discipline's tradition), in short, everything that belongs to self-reflexive research into scholarly practices and the production of knowledge. Also, a part of this, to a certain extent, is the dis/loyalty to the "fashion" in scholarship, which has been a typically global phenomenon, not only today, but even a century or two ago. Science is global or international, therefore local disciplinary traditions get caught in it in a varying dynamics, sometimes sooner, sometimes later, and more or less intensely. After all, this is the starting point and condition for our international communication. And if I had to single out one of the several authors that have made an important contribution to expand the field of issues related to the discipline's history, it would surely have to be George W. Stocking, Jr.

Even in the most difficult times - which for our forerunners were the decades following World War II, for which it often seems that the socialist regime was firmly closing the door to the experts hoping for a comparative dialogue, they were actually able to find a way and ensure it. In this respect, the Yugoslavian regime as compared to other countries of the so-called Eastern, socialist block, 
was "softer". My generation experienced hard times, but of course to a much lesser extent, in the 1980s when the "Yugoslav crisis" was severely limiting our financial options. The majority was thus mostly keeping in touch with the international science through reading rather than mobility. It is difficult to imagine it today how valuable each foreign book or journal was to our libraries that had to buy it.

\section{WORKING AT UNIVERSITY}

I was employed by the Faculty of Arts for almost two decades. This was an exceptional time for my maturing, both professionally and personally, and marked by my studies as well as generations of students. When taken seriously by the lecturer, teaching is demanding and strenuous. In recent decades, this responsibility might have grown due to the exceptional production of findings in the discipline and outside it, making it quite difficult to follow. In such circumstances we can only dream of the meticulousness of our older professors. Today, we are faced with a much different style of production within the discipline, often much shallower and more cursory as compared to the impressions acquired when reading older texts. However, a teacher first and foremost has to open the doors and windows to knowledge, curiosity, and responsibility, but also sensitivity both to the distinctions in the issues being raised today and to the style of research.

\section{WORKING AT A RESEARCH INSTITUTE}

Somehow, I also experienced this when changing jobs. That is to say, about a decade ago I moved from the university to a research institute with different work routines. Here I am allowed more time, which I missed while lecturing, so enabling me "slower" and more in-depth study and writing.

\section{OUR INSTITUTE}

The Institute of Slovenian Ethnology at the Research Centre of the Slovenian Academy of Sciences and Arts, where I work now, alongside the Institute of Ethnomusicology, is the central solely research-oriented institute for ethnology and folklore studies. Similar to university, where teaching is connected to research, the latter here is connected to teaching, although the scale is 
smaller. Namely, many researchers teach as external or guest lecturers at four Slovenian universities (Ljubljana, Maribor, Koper, Nova Gorica - the latter hosting a special RC SASA postgraduate programme). I also kept lecturing in Ljubljana for a year, then several years in Koper, at the Faculty of Humanities, where there is a department for cultural studies and anthropology. Research and teaching is a good and tempting combination, enabling the researcher to transfer their findings and test them in a way, particularly as regards their relevance and applied aspects. Above all, working with students forces you to keep in touch with the latest results in domestic and foreign scholarship. And simply enables you not to grow old.

As I have said already, the nature of work in a research institute is much different. In Slovenia, research institutes are financed through local and international research project tenders, therefore our survival depends on the success of our applications. Sometimes, this means cruel battles and competition, as in principle there is no stable finance for continuous research. I am particularly referring to fundamental research, which provides for a continuity of research relevant to the national culture, the knowledge of which is crucial for any intercultural comparison. The institute is currently implementing the research programme "Cultural Spaces and Practices: Ethnology and Folklore Studies" (2009-2014), with everybody employed at the institute participating in it (currently there are 17 people, of whom eight are $\mathrm{PhD}$ researchers, four young researchers, a documentation assistant, a secretary, a librarian, a research assistant and a technical assistant), and several projects with researchers participating based on their specific competences. This is the reason that our work unfortunately is often more fragmentary than we would have wished for, as intense input is required within several research projects. On top of the fact that the institute takes care of its archives and documentation, it keeps its own library and a special audiovisual laboratory that develops visual researches into culture and provides a large video archive. Senior researchers also serve as mentors to young ones who are training for their own academic career, completing their doctoral theses. We edit two scientific journals (Traditiones and Studia mythologica Slavica) and three book series (Opera ethnologica Slovenica, Ethnologica - Dissertationes and Slovenski pravljičarji [Slovenian Storytellers]).

Our editorial work is demanding in the sense of the amount of time it takes. I am particularly glad for both our journals to have an international profile, which has been achieved by being open thematically and having a rigorous editing process. Authors of articles are Slovenian and foreign researchers. We also publish topical volumes, often in English, to reach as many readers as possible in the international scholarly community. Also helpful in this view is our international editorial board with eminent foreign experts, two Slovenian 
academicians and experienced former editors. Except for the most recent year, the articles are also available on-line on the journal's homepage.

\section{PROFESSIONAL \& PRIVATE LIFE}

Ethnologists mostly believe ethnology to be life itself. And being unable to delineate my professional and personal life clearly, this is how I see it myself. At the institute I have my working space, which I use thoroughly in the morning, sometimes also in the afternoon and even on Saturdays and Sundays, if necessary. But this is far from saying that my work and my thoughts stop and switch over when I step out of the door of the institute. We cannot be like always in the field. Currently I have been involved in two new research projects exploring the transformation of festive practices and the issue of evaluating the relationship between nature and culture, i.e., natural and cultural heritage, with Triglav national park serving as an example, while I also continue researching the history and methodology of ethnology in Slovenia in a comparative European context.

On top of this fundamental work, the researcher often gets burdened with a plethora of minute, often bureaucratic tasks, which are also of key importance for the institute to function smoothly, while some others might support local ethnology at least indirectly. Considering all this, there is only little time left for leisure - for the family, walks, reading. I am thus looking forward to summer ever again, when I have the time to relax for a week or two in Slovenian mountains or somewhere in the Mediterranean, preferably in a quiet place somewhere on Croatian or Greek islands. But even then my spectacles have ethnological lenses.

\section{REFERENCES}

BA, 1981: Slovenci v Mannheimu. Poskus etnološko-jezikoslovne predstavitve. [Slovenians in Mannheim: An attempt at ethno-linguistic presentation.] Department of Ethnology, Faculty of Arts, University of Ljubljana.

Publ.: Slavec, Ingrid: Slovenci v Mannheimu. [Slovenians in Mannheim.] Ljubljana, 1982.

PhD, 1998: Med narodopisjem in antropologijo. Teoretsko-metodološka vprašanja in odgovori v etnologiji na Slovenskem. [Between narodopisje and anthropology: Theoreticalmethodological issues in Slovenian ethnology.] Department of Ethnology and Cultural Anthropology, Faculty of Arts, University of Ljubljana. 
Publ.: Slavec Gradišnik, Ingrid: Etnologija na Slovenskem. Med čermi narodopisja in antropologije. [Ethnology in Slovenia: between the reefs of narodopisje and anthropology.] Ljubljana, 2000.

\section{EDITED AND CO-AUTHORED BOOKS}

Slavec, Ingrid (et al., eds.). Etnološka stičišča / Zbieżności etnologiczne/ Ethnological contacts - 1. Ljubljana, 1988.

Slavec, Ingrid \& Dolžan Eržen, Tatjana (eds.). Zgodovinske vzporednice slovenske in hrvaške etnologije - 5. [Historical parallels of Slovenian and Croatian Ethnology.] Ljubljana, 1988.

Kremenšek, Slavko; Slavec, Ingrid \& Dolžan Eržen, Tatjana (eds.). Etnologija in domoznanstvo. [Ethnology and Heimatkunde.] Ljubljana, 1989.

Hribar, Daša; Jezernik, Božidar; Ostromecka-Fraczak, Božena \& Slavec Gradišnik, Ingrid (eds.). Etnološka stičišča / Zbieżności etnologiczne / Ethnological contacts - 3. Ljubljana, 1991.

Bogataj, Janez \& Slavec Gradišnik, Ingrid (et al., eds.). Kolesar s Filozofske. Zbornikv počastitev 90-letnice prof. dr. Vilka Novaka. [The cyclist from the Faculty of Arts: Papers honoring the 90th anniversary of Professor Vilko Novak.] Ljubljana, 2000.

Hudelja, Mihaela; Hazler, Vito \& Slavec Gradišnik, Ingrid. Podobe pokrajin 1956-1970. Etnološka fototeka Vilka Novaka. [Images of regions 1956-1970: Vilko Novak's ethnological photographs archive.] Ljubljana, 2001.

Slavec Gradišnik, Ingrid \& Ložar-Podlogar, Helena (eds.). Pretrgane korenine. Sledi življenja in dela Rajka Ložarja. [Displaced roots: the life and work of Rajko Ložar.] Ljubljana, 2005.

Slavec Gradišnik, Ingrid \& Ložar-Podlogar, Helena (eds.). Čar izročila. Zapuščina Nika Kureta (1906-1995). [The magic of tradition: the legacy of Niko Kuret (19061995).] Ljubljana, 2008.

Slavec Gradišnik, Ingrid (ed.). Etnološki pogledi in podobe. [Ethnological perspectives and images.] Ljubljana, 2009.

Slavec Gradišnik, Ingrid \& Radojičić, Dragana (eds.). Srbi v Sloveniji, Slovenci v Srbiji. [Serbs in Slovenia, Slovenians in Serbia.] Ljubljana, 2010.

Slavec Gradišnik, Ingrid (ed.) \& Ivančič Kutin, Barbara. Živa pripoved v zapisu. Kontekst, tekstura in prekodiranje pripovedi Tine Kravanja iz Bavšice. [A written record of live storytelling: context, texture, and transcoding of stories told live by Tina Kravanja from Bavšica.] Ethnologica - Dissertationes 3, Ljubljana, 2011.

\section{SELECTED ARTICLES}

„Historična etnologija“ ali o etnologiji kot vedi o preteklosti. [«L'ethnologie historique» ou l'ethnologie comme étude du passé.] Traditiones 1987, Vol. 16, pp. 51-72. 
Etnološko preučevanje etnične identitete slovenskih izseljencev. [Ethnological research of ethnic identity of Slovenian emigrants.] Dve domovini [Two Homelands] 1990, Vol. 1, pp. 309-317.

Slowenian ethnology between the past and the present. Ethnologia slavica 1990, Vol. 22 , pp. 217-242.

"The own" and "the foreign" or on the interpretation of cultural-ethnical-national differences. Etnološki pregled 1990, Vol. 26, pp. 87-98.

O etnologiji in leksikografiji. Slovenski etnološki leksikon med zamislijo in izidom. [On ethnology and lexicography: the lexicon on Slovenian ethnology between conception and publication.] Traditiones 2005, Vol. 34, No. 2, pp. 87-107.

"Narodu v slavo in učenosti v napredek". Recepcija Gregorja Kreka v slovenski etnologiji. ["To the glory of the nation and to the advancement of learning": the reception of Gregor Krek in Slovenian ethnology.] Anzeiger für slavische Philologie 2006, Vol. 33 (2005), pp. 93-113.

Etnološka branja Gregorja Kreka. [Ethnological readings of Gregor Krek.] Traditiones 2006, Vol. 35, No. 2, pp. 205-233.

Scraps of the history of ethnology in Slovenia. Česky lid 2008, Vol. 95, No. 1, pp. 37-62.

Pogledi in podobe. K vprašanjem o produkciji znanja I. [Perspectives and images: fragments of knowledge production in etnology I.] Traditiones 2008, Vol. 37, No. 2, pp. $217-250$.

Slovenian folk culture. Between academic knowledge and public display. Journal of folklore research 2010, Vol. 47, No. 1/2, pp. 123-151.

"Marxistický program" v slovinskej etnológii?. [The "Marxist" agenda in Slovenian ethnology?] Slovensky národopis 2010, Vol. 58, No. 4, pp. 478-495.

Etnologija v Sloveniji in Srbiji. Dve tradiciji “jugoslovanske” etnologije? [Ethnology in Slovenia and Serbia: two traditions of "Yugoslav" ethnology?] Traditiones 2010, Vol. 39, No. 1, pp. 15-30.

On folklore and folklore studies in Slovenia. Balgarski folklor 2011, Vol. 37, special edition, pp. 5-22.

Zadnje desetletje od šestih. Inštitut za slovensko narodopisje ZRC SAZU (1951/20012011). [The last of the six decades: the Institute of Slovenian ethnology ZRC SAZU (1951/2001-2011).] Traditiones 2011, Vol. 40, No. 1, pp. 115-138.

The Institute of Slovenian Ethnology ZRC SAZU (1951-2001). Ethnologia europaea centralis 2011, Vol. 10, pp. 81-86.

\section{CHAPTERS IN BOOKS}

Težnje v povojni slovenski etnologiji. [Trends in post-war Slovenian ethnology.] In: Bogataj, Janez and Marko Terseglav (eds.). Zbornik 1. kongresa jugoslovanskih etnologov in folkloristov: Rogaška Slatina, 5.-9.10.1983: 30. kongres Zveze društev folkloristov Jugoslavije: 18. kongres Zveze etnoloških društev Jugoslavije. Ljubljana, 1983, pp. 148-175.

Marginalia to ethnological writing and description. In: Etnološka stičišča / Ethnological contacts - 1, 1988, pp. 119-128. 
O identiteti etnologije [The identity of ethnology]. In: Rihtman-Auguštin, Dunja (ed.). Simboli identiteta [Symbols of identity]. Zagreb 1991, pp. 32-44.

Med narodopisjem in antropologijo: o razdaljah in bližinah. [Between ethnograhy and anthropology.] In: Muršič, Rajko and Mojca Ramšak (eds.). Razvoj slovenske etnologije od Štreklja in Murka do sodobnih etnoloških prizadevanj. [The development of Slovene ethnology: from Štrekelj and Murko to modern ethnological efforts.] Ljubljana 1995, pp. 125-140.

Redefinicija slovenskega narodopisja v objemu evropske etnologije ali "O bistvu etnografije in njeni metodi" - še enkrat. [The redefinition of Slovenian ethnography in the context of European ethnology: "On the essence of ethnography and its method" reread.] In: Bogataj, Janez et al. (eds.), Slavec Gradišnik, Ingrid (ur.). Kolesar s Filozofske. Ljubljana 2000, pp. 79-103.

Podobe pokrajin in njihovo ozadje. Kulturna območja na Slovenskem. [Images of regions and their background: Cultural areas in Slovenia.] In: Hudelja, Mihaela; Hazler, Vito \& Slavec Gradišnik, Ingrid. Podobe pokrajin (1956-1970). Etnološka fototeka Vilka Novaka. [Images of regions 1956-1970: Vilko Novak's ethnological photographs' archive.] Ljubljana 2001, pp. 25-59.

O Ehrlichu in etnologiji. [On Lambert Ehrlich and Ethnology.] In: Škulj, Edo (ed.). Ehrlichov simpozijv Rimu. [Lambert Ehrlich Symposium in Rome.] Celje 2002, pp. 157-172.

Bogastvo filologije. Murkov pomen za etnologijo v Sloveniji. [The affluence of philology: Matija Murko's significance for ethnology in Slovenia.] V: Matija Murko v myšlenkovém kontextu evropské slavistiky : sbornik studii. [Matija Murko in the intellectual frames of European Slavic studies.] Brno 2005, pp. 100-122.

Etnološki nazori Rajka Ložarja. [Ložar's View on Ethnology.] In: Slavec Gradišnik, Ingrid \& Ložar-Podlogar , Helena (eds.). Pretrgane korenine. Sledi življenja in dela Rajka Ložarja. [Displaced roots: the life and work of Rajko Ložar.] Ljubljana 2005, pp. 283-303.

Slovanski svet v obzorju slovenske etnologije. [The Slavic world in the horizon of Slovenian ethnology.] In: Kaleta, Petr \& Tyllner, Lubomír (eds.). Slovanský svět očima badatelů a publicistů 19. a 20. století. Praha 2007, pp. 209-225.

Med življenjem in znanostjo. Etnološka obzorja Nika Kureta. [Between Life and Scholarship: Niko Kuret's ethnological horizons.] In: Slavec Gradišnik, Ingrid \& Ložar-Podlogar, Helena (eds.). Čar izročila. Zapuščina Nika Kureta (1906-1995). [The magic of tradition: the legacy of Niko Kuret (1906-1995).] Ljubljana 2008, pp. 41-68. 
Ljubljana - preddverje slovenske urbane etnologije. [Ljubljana: an antechamber to Slovene urban ethnology.] In: Čebulj - Sajko, Breda (ed.). Etnologija in regije, Ljubljana, Urbana etnologija in identitete Ljubljane. [Ethnology and regions: Ljubljana: urban ethnology and Ljubljana's identities.] Ljubljana 2008, pp. 17-29.

Institucije in produkcija etnološkega znanja. [Institutions and the production of ethnological knowledge.] In: Divac, Zorica (ur.). Slike kulture nekad i sad. [Images of culture then and now.] Beograd 2008, pp. 65-79.

(with Jurij Fikfak). Gradec in slovensko narodopisje. [Graz and Slovenian ethnography.] In: Karničar, Ludvik \& Rajšp, Vincebc (eds.). Graz und Slowenen: Sammelband zum gleichnamigen Symposium vom 20.-21. V 2010 an der Karl-Franzens-Universität Graz. Wien, Ljubljana \& Graz 2011, pp. 115-129. 